International Journal of English Language Studies (IJELS)

ISSN: 2707-7578

DOI: $10.32996 /$ ijels

Website: https://al-kindipublisher.com/index.php/ijels

\title{
American English in Teaching English as a Second Language
}

Mammadova Gunay Aqil

Department of English Phonetics, Azerbaijan University of Languages, Baku, Azerbaijan

Corresponding Author: Mammadova Gunay Aqil, E-mail: gunaymemmed24@gmail.com

\section{ARTICLE INFORMATION}

Received: December 28, 2020

Accepted: February 15, 2021

Volume: 3

Issue: 2

DOI: $10.32996 /$ ijels.2021.3.2.7

\section{KEYWORDS}

American English, British English, ruining English, teaching English as a second language

\section{ABSTRACT}

With the lapse of time the two nations- Americans and British always blamed each other for "ruining" English. In this article we aim to trace historical "real culprit" and try to break stereotypes about American English status in teaching English as a second language. In comparison with Great Britain the USA has very short and contemporary history; nevertheless, in today's world American English exceeds British and other variants of English in so many ways, as well as in the choices of language learners. American English differs from other variants of the English language by 4 specific features: Inclusiveness, Flexibility, Innovativeness and Conservativeness. Notwithstanding, British disapprove of Americans taking so many liberties with their common tongue, linguistic researcher Daniela Popescu in her research mentions the fields of activities in which American words penetrated into British English. She classifies those words under 2 categories: everyday vocabulary (480 terms) and functional varieties (313 terms). In the case of functional varieties, the American influence is present in the areas of computing (10\%), journalism (15\%), broadcasting (24\%), advertising and sales (5\%), politics and economics (24\%), and travelling and transport (22\%). Further on, the words and phrases in the broadcasting area have been grouped as belonging to two areas: film, TV, radio and theatre (83\%), and music (17\%). The purpose of the research paper is to create safe and reliable image of American English in the field of teaching English as a second language. Americans are accused in "ruining" English and for that reason learners are not apt to learn American English. The combination of qualitative and quantitative methods is used while collecting the data. The study concluded that the real culprits are British who started out to ruin English mainly in in the age of Shakespeare and consequently, Americans inherited this ruin from the British as a result of colonization. Luckily, in the Victorian Age British saved their language from the ruins. The paper discusses how prejudices about American English effect the choices of English learners.

\section{Introduction}

Admittedly, English is not a language of communication used with uniformity only in Britain, but also in Australia, in the USA and in New Zealand, in Canada and in India, etc. In every part of the world this language has its own peculiarities significantly different in the sound system, vocabulary and in own literary norms. For the first time such kind of spread of English is captured by Braj Kachru in terms of "Three Concentric Circles of the Language": The Inner Circle, the Outer Circle, and the Expanding Circle (Kachru, 1992). Only these two main variants, British and American English was discussed and debated over half a century. Only these two variants have been linguistically studied well in comparison with other variants. The reason is that the English language was institutionalized only in the USA and UK. Colonization of Great Britain spread English to every corner of the world and made it a global and international language. To some experts, on the other hand it spoiled the pureness of the language and made it difficult to become a standard language because of its variants. So, for these reasons, British English was always considered to be more prestigious variant in comparison with the other ones, and for some unknown reasons American English is very often thought to be incorrect variant of British English, however it is the one of the widespread and most recognized variant of English which owns an individual grammar, lexicology and distinctive phonetics. Having peculiar grammatical structure is enough to

K C AL-KINDI CENTER $\mathbf{R}$ FOR RESEARCH AND $\mathbf{R}$ DEVELOPMENT Your gateway to world-class research

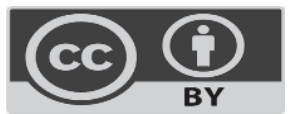

Published by Al-Kindi Center for Research and Development. Copyright (c) the author(s). This open access article is distributed under a Creative Commons Attribution (CC-BY) 4.0 license 
prove American English to be not only a variant, but also language from our point of view. American English reckoned to be more concise and much more economical in comparison with British English.

The paper focuses on academic usage of American English in teaching English as a second language. In the first step it is necessary to briefly review some general assumptions about the history of American English. Secondly, in order to demonstrate the influential status of American English I will introduce a classification of English words offered by Daniela Popescu that penetrated to British English from American English. In the chapter named "Who is the real culprit, Americans or British?" I will present close analysis of claims made against Americans and draw positive conclusions which will be decisive in favor of American English. Subsequently, based on explanations I will have a brief discussion in order to give an outlook on why educators don't prefer American English in the teaching process of English.

\subsection{American English and its formation}

Americans represents the majority of world's native speakers of the English language which is approximately 240 million people in comparison with Britain's native speakers (57 million people) $($ Tottie ,2002) The English has been official and de facto language in the 32 states of the USA used by federal government Obviously, in comparison with the history of the English Language American English is relatively short. Throughout the centuries as a result of continuous process "Americanism" was formed and changed and developed from other British words and terms to create a standardized language system which significantly differs from ancestors symbolizing uniqueness and independence. American Revolution had a paramount influence on the creation of separate and standard American English. People were determined to gain their independence in every respect. At one point even they yearned for adopting a totally new language which was proposed to be French, German and, surprisingly Hebrew. Since implementation of these languages was virtually impossible, they came to the common ground about adopting English as a defacto language of the USA. Creation of unique English in America full of new words with new way of spelling and new structures fueled with American patriotism ( who really felt that American English was much superior to British English) and at the same time Declaration of Independence paved a way to so many innovative ideas and their implementations and it gave an impetus to an innovator and fierce patriot lexicographer Noah Webster who always advocated the idea of using different spelling system from that of British English. He succeeded to compile "Spelling Book" in 1783 which was one of the volumes of his great "A Grammatical Institute of the English Language". Webster reflected his fierce patriotism in his quote like this; "As an independent nation, our honor requires us to have a system of our own, in language as well as government." (Webster, 1789 quoted in Tottie, 2002) So, the formation and development processes of American English fall into three periods which coincides with the factors which Strevens explains on its difference from British English. The first Englishmen set his foot upon American soil 400 years ago, to say it exactly in the beginnings of 17th century as a consequence of colonization. The people who constituted the early colonies were strongly in opposition with the Church of England or couldn't make a better living there and obviously they were not the cream of Britain society. When tobacco caught on, for this time America became more attractive for those with money who were owners with insufficient servants and slaves. Consequently, the earliest American English was strongly influenced by the dialect of the people who were still British, nevertheless, currently that sort of language is not highly esteemed by those with money in America. Some words which British consider "Americanism" were actually British originally spoken in the colonies while lost for some period in Britain. (for instance, mad for angry, fall for autumn, trash for rubbish.) All the processes began in 1607 and this is called "Colonial Period" in the history of American English. The formation of colonies was continuous process and came to an end with the formation of 12 colonies in 1776. This period is distinguished for the birth of distinctive American English.

The USA is a large country and every group of immigrants brought distinct flavors to English now spoken and written in America. In addition to British settlers, immigrants from different European countries steadily moved to New World. Dutch, French, Scots-Irish and Germans once inhabited there, their speech started to get localized. Surprisingly, the influence of Africans brought through Slave Trade was relatively small on the formation of American English. It is important at this point to mention that, besides this enormous flux of immigrants America had its own indigenous people speaking in Native American Languages which were Algonquian, Muskoghian and Penutian. These languages contained nasal, pharyngialised and glottalised sounds which were unfamiliar to immigrants, however, native languages were great source of words and expressions for them to describe new experiences in their new homeland. Inevitably, all the words borrowed from natives were assimilated in form and meaning. All these processes which reflected the Americans own growth and development (Natioanal Period, 1776- 1898) were the motives for American English to be different from British one. And this the second factor stated by Strevens in his research. Despite the myth "American English is the altered variant of British English" British English began to encounter idiosyncratic changes earlier than American one, even accent itself has changed more in comparison with American English. According to Strevens (Strevens, 1972) there exist three factors which led to differences between American and British English. The first factor is connected with the changes happening in Britain itself. 


\subsection{The penetration of American English into Britain one}

In International Period (from 1898 up to now) American culture began to penetrate into every culture of world's nations including Great Britain. Increasing role of the USA in politics and business, at the same time, spread of American pop culture and films throughout the world resulted in its influence and penetration into other varieties of the English language, especially British one. This is the third factor stated by Strevens.

Daniela Popescu in her research mentions the fields of activities in which American words penetrated into British English. (Popescu,2012) She classifies those words under 2 categories: everyday vocabulary (480 terms) and functional varieties (313 terms); "In the case of functional varieties, the American influence is present in the areas of computing (10 \%), journalism (15\%), broadcasting (24\%), advertising and sales (5\%), politics and economics (24\%), and travelling and transport (22\%). Further on, the words and phrases in the broadcasting area have been grouped as belonging to two areas: film, TV, radio and theatre (83\%), and music (17\%)". It may seem paradoxical to many of us why Britain allow Americanism to take so many liberties with their tongue while they every time denounce it. They just desire to communicate with Americans intelligibly; they do not want to be Americans at all. A BBC journalist Hephzibah Anderson (Anderson,2017) complains about the situation in his article that, "So it turns out I can no longer speak English. This was the alarming realization foisted upon me by Matthew Engel's witty, cantankerous yet nonetheless persuasive polemic. That's the Way it Crumbles: The American Conquest of English. Because, by English, I mean British English". H. L. Mencken (Mencken, 2009) spoke of two individual languages with a constant flood of linguistic influence first (up to about 1914) from Britain to America and since 1914 from America to the British Isles. Nevertheless, Americans admit their love and give royal and warm welcome when British royalty visit the USA., but anyway, they celebrate the day when they became independent from Britain Colony.

\section{A review of the literature}

John Algeo (Algeo, 1998) in his popular "America is ruining the English Language" gives pretty good information about the public figures (Prince Charles, Edwin Newman) who made a public accusation against Americans for spoiling the language. His royal highness the Prince of Wales was reported by the Times as complaining to a British Council audience that American English is very corrupting. One may claim that Prince Charles words as an argument and evidence against American English's reputation, but taking into consideration that Prince Charles is the member of Royal Family and naturally he speaks RP and British English is the purest variant of the English language from their perspective, and thereafter American English is very often thought to be incorrect variant of British English, however it is the one of the widespread and most recognized variant of English. Edwin Newman- linguistic prophet as Algeo calls him considers speech of his American friends deadly. In his book (Newman, 1974) "Strictly Speaking" in subtitle "Will America be death of English?" he objects to newly created nouns and verbs that shouldn't be.

\section{Methods}

While investigating the research topic we have mainly used mixed methods which is the combination of qualitative and quantitative in itself. The appropriateness of the methods gives a guarantee to the reliability and validity of the presented data in the research paper.

\section{Statement of the problem}

Generally, the learners who wish to master other languages learn only one language. The main distinguishing and difficult feature of mastering English is that there is not one single standard form of the language. Majority of linguistic experts of the worldwide universities consider British English to own deep linguistic roots which preserved its poorness from external affects and at the same time it is reckoned to be the most prestigious variant contrary to American English. In many European countries at schools and universities British English dominate in teaching process. The professors, lecturers and instructors of the university have a British English background. Instructors are not allowed to teach and communicate in American English. Taking into consideration that learning process is the investment of time and financial resources both by educational establishment and learners and experts have to think over the issues like which variant is likely to provide the best return. In general term, learners and teachers all over the world have prejudices about American English. The prime reason for that is the British's blaming Americans for "ruining" English and disapproving of their taking so many liberties with their common tongue. The biggest prejudice about American English is that it is considered to be corrupt and inappropriate for academic usage safe to say in all over the world. In response to this problem our research paper aims to investigate who is indeed spoiling the English language and by this way we target to create safe and reliable image of American English in the field of teaching English as a second language.

\section{Who is the real culprit, Americans or British?}

For now, let's hypothesize that, Americans are ruining English. Are Americans "linguistic criminals"? So, Americans are accused in the following changes: 


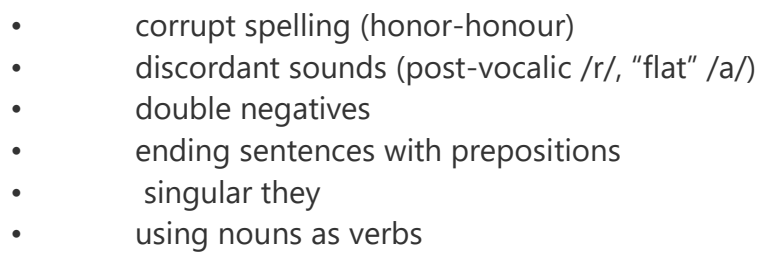

In order to analyze the first option, we would like to take Shakespeare's plays as an example. The reason for that is this genius man is reckoned to be the one who made English prestigious by writing in an accurate way. Interestingly, Shakespeare, the bestknown source of Modern English, deviated some words in his plays. The word "honour" is found 393 times in the First Folio of Shakespeare's plays (published in 1623), while the spelling "honor" occurs 530 times. "Humour" scores 47 while "humor" is used 90 times. The spelling "center" is found nine times, while "centre" occurs only once; "sceptre" occurs four times, but "scepter" 36. In spite of all these facts, "or" and "er" ending words (honor, neighbor, center, color) are righteously considered to be the Webster's reforms. Another fact to be discussed is the invention of printing. All admit the profound effect of Caxton's idea on the stabilization of English spelling, thus in his age there was not a single rule regulating stable spelling and pronunciation. So, that is why, everybody had expected Caxton to print in their way of speaking and writing. As it was beyond the realm of possibility to receive all the criticisms and agree to make all the corrections, he only accepted to make amendments when Lady Margaret (sister of Kind Edward IV) found mistakes in his printings.

The post-vocalic / $r$ / in Standard American was actually pronounced in Middle English period by all classes and in all regions of the country, until the 15th century. Somehow it disappeared gradually. Still there are some dialects of British English, Scots and West Country which still articulate the post-vocalic / $r$. The same case is the opposite with American English. Nonstandard varieties like Eastern Massachusetts and African-American Vernacular English lack the "rhotic" sound.

When it comes to double negatives, it is a common knowledge that, in British English you can't use double negatives in the same sentence, for instance, the sentence "I can't get no pleasure" is grammatically incorrect, since you should use "any" instead of "no". Some scholars pedantically claim that double negative implies affirmation; nevertheless, there exist a number of languages which logically use double negatives to express negation. Generally double negatives are unacceptable in Standard American English, though it is used as a red herring against American English.

Next judgment is sentence final prepositions which mean you mustn't end any sentence with a preposition. On this issue we can only cite from is the only perfect man who read Oxford Dictionary cover to cover. The notion that you should not end a sentence with a preposition, it came up in 1646. A grammarian named Joshua Poole decided he didn't like prepositions at the end. (Shea, 2014) It was transferred from century to century from generation to generation, anyway it doesn't spoil or ruin the structure of language or the content if we use preposition at the end and it totally acceptable in both variant of English.

"How using 'they' as a singular pronoun can change the world" quotes the writer and educator Davey Shlasko and everybody owes idiosyncratic opinion about singular they. One of the main excuses that people give for not using singular they is that it is "grammatically incorrect." This belief comes less from a nuanced understanding of grammar than from a felt sense that one is doing something wrong by using singular they. To some ear" singular they" might sound "odd" because everybody is disciplined in school to stop using they as a singular. In his "Trans Allyship Workbook" Davey Shlasko writes: "The rule against using singular they is enforced neither because it preserves some consistent, objective grammatical standard, nor because it serves our communication needs. It is enforced because enforcing language norms is a way of enforcing power structures". (Shlasko, 2017) "Singular they" was adopted since long before when gender used was unknown. Words like "someone," "anyone," and "whoever." That It's syntactically singular but logically plural refer to singular they, for instance, "Everyone knows their own character well. We could say, "Everyone knows his/her own character well". We can see this case as an old problem in Chaucer's works: "And whoso fyndeth (find) hym out of swich blame, / They wol come up" But whoso finds himself without such blame/ He will come up and offer, in God's name (The Canterbury Tales of Chaucer, 1775)

The last thing which Americans are accused to ruin is the verbing nouns that are called conversion in the grammar books. This grammatical tradition comes from early Middle English period. It reached its culmination in the 16th and 17th centuries, from that time up to modern day it declined slightly. To put it in a nutshell Americans are not using verbing so frequently like Englishman were doing in his plays, for instance, "Grace me no grace; nor uncle me no uncle" (Richard II)

\section{Discussions}

It is a common knowledge that by some reasons American English was always reckoned to be "slangy" on the contrary to British English which is perceived to be "noble", "royal" and much older. British think of their language to be traditional and more 
institutionalized. For academic staff American English is inappropriate since it doesn't own stable grammatical and phonetical structure, so it is not taught in academic level at educational institutions. The USA's dominant culture and economic policy, especially "Hollywood" films access to every country paved a way to American English to penetrate into every culture of world's nations including Great Britain. We can safely say that a language or variant gains authority and popularity when the nation gains dominance over other nationalities due to their political and cultural peculiarities. So, consequently, in the few last decades the USA "propaganda" made great progress. Taking all these things into consideration American English must be taught at schools and universities for meeting learners and students' requirements. They have to know how to cope with the different speakers who use different variants of English. According to the result of the investigation we came to decision that American English deserves to be taught at educational institutions for its 4 specific features which differs it from other variants of English:

1) Inclusiveness: As America has hosted many nations like German, French, Scottish, Dutch, Italian and Spanish American English includes the remnants of the languages of these nations. With this we can say that American English is more inclusive, more comprehensive language in proportion to other variants and it meets international students' communication needs more successfully than British English do.

2) Flexibility: American English is flexible because words are more inclined to new forms and to fulfill the real needs; the word "white collar" actually means "white collar" but within the framework of capitalism this word means "the worker who works at the office.

3) Conservativeness: Americans do not extract the words from lexicon which was used in medieval England, but have been forgotten in modern British English, they have tried to protect and strengthen medieval words in the language. The American word "fall" conveyed the meaning "autumn", so to say it exactly, the word "fall" was used instead of "autumn" in medieval period. Thus, with this character American English is equal to "traditional" British English in teaching English as a second language or in other sectors of education field.

4) Innovativeness: It is a common knowledge that that Americans are always different for their great courage and high creativity. New words and forms have occurred related to social and technological development. For instance, the word "test-tube baby" in medicine and "soup opera" in media sector. Today's educations system is in search of innovative brains and innovative brains always innovate new ideas. We do believe that, American English is innovative enough for modern type of education system.

\section{Conclusion}

To put it in a nutshell, the word "ruining" implies the notion "changing something in a negative way". Like it or not, like other realities of existence language too do changes as it is inevitable. Supposedly, such kind of negative changes endangers the capacity of language, simplifies complicated system of historical language. Consequently, complex thoughts and exquisite arguments can't be expressed with simplified system. It is indeed debatable whether simplification is good or bad for language, but it not the case for us.

The possible first conclusion is that as mentioned above "destroying language" has nothing to do with language, it is the matter of "regular changes" happening in the language and "cultural dominance". The second possible conclusion, we can safely that, the main problematic issue of the English language, is that of lack of linguistic academy. In 1712 the poet and satirist Jonathan Swift attempted to establish an academy similar to the Académie française established by Cardinal Richelieu in 1635. In his 1712 "Proposal for Correcting, Improving and Ascertaining the English Tongue," Swift (Beal,2004) wrote that English is extremely imperfect; its daily Improvements are by no means in proportion to its daily Corruptions; it offends against every Part of Grammar. He had some worries about the future destiny of English as he thought that people would forget the history of their words, so English needs protecting. The third and the final conclusion is that the real culprits are British who started out to ruin English mainly in in the age of Shakespeare and consequently, Americans inherited this ruin from the British as a result of colonization. Luckily, in the Victorian Age British saved their language from the ruins. When it comes to attitudes of the last decades American English now shares the same values with British English. However, according to Americans' proclamation, American English will have influence on British English so powerfully that there will come a time when American standard will be established in Britain itself.

Based on the conclusion of the study, the researcher puts some suggestions to the following parties as teaching process involves both teachers and students:

\subsection{The Students}

The conclusion of the study indicates that accusations against Americans on ruining English is baseless. The students need to have an in-depth research about perspective of American English which is likely best return in the learning process of English. 
They also need to increase their awareness of American English and break stereotypes by filling the gaps doing researches about history of its linguistic peculiarities.

\section{2 The Teachers}

There are still many aspects which can be analyzed about "ruining" issues of the English language. Finally, other researchers can analyze other issues like "totesing" which Americans are blamed to ruin the language for. It is hoped that this research can encourage teachers to enlighten students about the linguistic peculiarities of American and British and in the very first lesson in order let them not to be biased about any of both international dialects.

\section{References}

[1] Algeo, J. (Ed). (1998). Language Myth: America is Ruining the English Language. Edited by Laurie Bauer; Peter Trudgill. London, Penguin Books

[2] Anderson,H.(2017, 6spetember). How Americanisms are killing the English Language. Retrieved from http://www.bbc.com/culture/story/20170904-how-americanisms-are-killing-the-english-language

[3] Ammon, Sh. (2014). Bad English: A History of Linguistic Aggravation. New-York, Penguin Books

[4] Beal.C.J. (2004). English in Modern Times. London, Arnold

[5] Davey,Sh, (2017). Trans Allyship Workbook. Guilford,Think Again Training

[6] Kachru, B. (1992). The Other Tongue: English across cultures. Urbana and Chicago, University of Illinois Press

[7] Mencken, H.L. (2009). The American Language. New-York, Cosimo Books

[8] Newman, E. (2010). Will America Be Death of English. Transaction Large Print

[9] Popescu, D. (2012).Influence of American English on British English, Retrieved from https://doctorat.ubbcluj.ro/sustinerea publica/rezumate/2011/filologie/popescu daniela en.pdf

[10] Strevens, P (1972). British and American English. London: Collier-Macmillan

[11] Swift, J. (1712). Proposal for Correcting, Improving and Ascertaining the English Tongue. .London

[12] Tottie.G ,(2002) .An Introduction to American English. Malden, Blackwell Publishers

[13] Webster. (1789). quoted in Tottie, G. (2002). An Introduction to American English. Malden, Blackwell Publishers 